\title{
INHERITANCE OF SOME FRUIT CHARACTERS AND RESISTANCE TO ROOT-KNOT NEMATODE, MELOIDOGYNE INCOGNITA, IN TOMATO (SOLANUM LYCOPERSICUM, L.)
}

\author{
Mona R. Khalil(1) and M. Z. El-Shennawy ${ }^{(2)}$ \\ (1) Horticulture Dept., Fac. of Agric., Menoufia Univ., Shibin El-Kom, Egypt. \\ (2) Agricultural Botany Dept., Fac. of Agric., Menoufia Univ., Shibin El-Kom, Egypt.
}

Received: Jan. 11, 2017

Accepted: Apr. 15, 2017

\begin{abstract}
This study was carried out at the Experimental Farm, Faculty of Agriculture, Menoufia University, Shibin El-Kom during three summer seasons. The cultivar Super Beef Steak and the line $B \mathrm{l}-15$ were used as parents to produce the required populations, i.e., $F_{1}, F_{2}$ and $B c p_{1}$ and $B c p_{2}$. The six populations were evaluated for number of days to the first ripe fruit, average fruit weight, total soluble solids and ascorbic acid content, as well as, resistance to the root knot nematode, Meloidogyne incognita. A randomized complete blocks design was used. Data were recorded on an individual plant for each population. Regard to the resistance to root knot nematode, the experiment was carried out in pots. Data obtained suggested that the number of days to ripening showed over-dominance for the short period. Total soluble solids and ascorbic acid contents are controlled by additive gene with slight dominance for the low contents. Partial dominance for the small fruit was found. With regard to root knot nematode resistance, the character is controlled by single dominant gene for low number of galls and egg masses. Therefore, developing of tomato cultivars and $F_{1}$ hybrids for resistance could be achieved by breeding programs.
\end{abstract}

Key words: Dominance, partial dominance, additive, segregation, egg masses and gall number, genetic advance.

\section{INTRODUCTION}

Tomato (Solanum lycopersicum L.) belongs to the family Solanaceae, which is believed to consist of 96 genera and over 2800 species distributed in three subfamilies: Solanoideae (to which Solanum belongs), Cestroideae and Solanineae (Knopp et al., 2004).

Today fruit quality and disease resistance are a major focus of most breeding programs. The major fruit quality traits of interest to both fresh market and processing tomato industries being fruit size, shape, total soluble solids (TSS \%) and vitamin C contents, as well as, other characters such as lycopene, $\beta$-carotene, fruit firmness and flavor (Foolad, 2007).

The inheritance and type of gene actions of earliness were studied by several investigators. Nassar (1988) reported that about $86 \%$ of the variability in early yield among hybrids or cultivars of tomato was dependent on the genotype.

Number of days from transplanting to first ripe fruit was controlled by a single pair of genes with complete dominance of the short period to maturity and requires presence of many minor genes (Ahmed et al., 2006), indicating importance of the additive gene action for controlling this trait and suggesting that selection may be beneficial for improvement the early maturity. The number of days to maturity was controlled by a single pair of genes with dominance to the short period to maturity and presence of some additive gene effects (Midan et al., 2009).

Regarding average fruit weight, positive heterosis was found in some studied (Ahmed et al., 2011). High BSH (96.5\%) and genetic advance (52.44) values were observed by Rajesh et al. (2006). High heritability associated with high genetic 
advance were also observed for individual fruit weight by Ghosh et al. (2010) and Rajasekhar et al. (2013).

Regarding to TSS\% content, Khalil et al. (1986) found that, the trait was quantitatively inherited with additive gene action and slight dominance of high content. Also, Shirin and Hazra (2013) reported that, additive and dominance components were highly significant and important for conditioning this trait. Heterosis relative to mid-parent (Megahed, 2002 and Masry, 2014) as well as better parent (Singh et al., 2008) were reported for TSS\% content. Meanwhile, negative MPH \% and no-dominance for this trait were observed by Yashavantakumar (2008) and Mostafa (2015), respectively. The estimated narrow sense heritability (NSH) was moderate $(57.43 \%)$ as reported by Shirin and Hazra (2013). Both heritability and genetic advance under selection were high (Rajasekhar et al., 2013).

For vitamin C content, all degrees of dominance were observed in different tomato $F_{1}$ crosses by many workers. Significant positive MP-heterosis was found by Megahed (2002) and Mostafa (2015). While significant negative MP-heterosis was detected by Tendulkar (1994). Regarding to BP-heterosis, Kumar and Sharma (2011) found positive values. On the other hand, it was significantly negative (Mahendrakar, 2004). The study of Mostafa (2015) revealed partial, complete and over- dominance for the high vitamin $\mathrm{C}$ content. High $\mathrm{BSH}$ with high genetic advance as percent of mean (GAM) were recorded for vitamin C content, indicating predominance of additive gene action for this character. Simple selection based on phenotypic performance would be more effective (Rajasekhar et al., 2013) for improving this trait.

Concerning the root-knot nematode disease according to Roberts and May (1986) susceptible cultivars loosed until $50 \%$ of yield due to infections $M$. incognita in tomato and the resistant cultivars were unaffected. Positive correlation between damage levels of roots, egg mass number and second stage larvae population in the root was significant (Rudi et al., 2012).

Few studies have been conducted on the inheritance of resistance to root-knot nematode in tomato. Khalil and Salem (1983) found that this character was simply inherited with complete dominance of the resistance over susceptibility. They added that BSH was estimated as $62.4 \%$, indicating that selection on the individual plant basis could be successfully to improve resistance level. Mark (1986) also reported that the resistance may be under control of a single gene locus in tomato.

Recently, El-Shennawy and Khalil (2014) stated that both additive and non-additive gene effects were involved in the inheritance of this trait. GCA: SCA ratio revealed that GCA effects were play the main role, indicating that the resistance degree could be improved by selection.

\section{MATERIALS AND METHODS}

This study was conducted at the Experimental Farm, Faculty of Agriculture, Menoufia University, Shibin El-Kom, Egypt during three summer seasons, (2014 2016). In the first season two parental genotypes, i.e., Super Beef Steak cultivar and Cherry line (BL-15), which were widely differed in their traits and have high degree of homogeneity were used in the study. The seedlings were transplanted in the field and the crossing was made between the two parents to produce the $F_{1}$ seeds. The $F_{1}$ and the two parents were grown in the second season. The $F_{1}$ plants were selfed and backcrossed to both parents to develop the required $F_{2}$ and backcrosses seeds. In the third season (2016), the six populations, i.e., $\mathrm{P}_{1}, \mathrm{P}_{2}, \mathrm{~F}_{1}, \mathrm{~F}_{2}, \mathrm{Bcp}_{1}$ and $\mathrm{Bcp}_{2}$ were grown in a field experiment to evaluate some characters i.e., number of days from transplanting to fruit ripening, average fruit weight, total soluble solids (TSS\%) and ascorbic acid contents (vitamin C). 
A randomized complete blocks design with three replicates was used. Each replicate of the six populations was represented by 1-4 ridges, the ridge contains 10 plants. The number of ridges was, one for each of the non-segregating populations, three for each of $\mathrm{Bcp}_{1}$ and $\mathrm{Bcp}_{2}$ and four for the $F_{2}$ populations. The ridge was 4 meters long and 1 meter wide with spacing of $40 \mathrm{~cm}$ within plants. Fertilization, irrigation, disease and insect control programmes were carried out as usual in tomato.

Data were recorded on an individual plant of each population regarding the studied characters (number of days from transplanting) to the first ripe fruit, average fruit weight, total soluble solids (TSS) and ascorbic acid (vitamin C) contents. The latter three characters were determined at the third harvest for five fruits per plant.

In the same season (2016), pots experiment were carried out to test the degree of resistance to root-knot nematode disease for the six populations. Two seedlings (five weeks old) of each population were planted in plastic pots ( $25 \mathrm{~cm}$ diameter) filled with $4 \mathrm{~kg}$ of sterilized soil. A Randomized Complete Blocks Design with three replicate was used. Total number of plants for each population were 30 for the non-segregating populations, 90 for each backcross and 108 for $F_{2}$ populations.

Two-months-old night shade (Solanum nigrum L.) infected roots with Meloidogyne incognita was washed with tap water to remove adhering soil particles, cut into small pieces (approximately 1-2 cm) and vigorously shaken in a bottle containing $0.5 \% \mathrm{NaOCl}$ for 3 min according to Hussey and Barker (1973). After that the eggs were collected on $38 \mu \mathrm{m}$ sieve and washed in a beaker. The egg suspension was transferred to Baermann trays with soft tissue paper at room temperature to allow egg hatching. After 96 hours, the freshly hatched second stage juveniles were standardized and concentrated.

After one week, $1000 \mathrm{~J}_{2}$ M. incognita were added by pipette around each seedling. Pots were irrigated as needed and fertilized every three weeks, Greinzet NPK solution (50 $\mathrm{ml} / 10$ liters water) either added to the soil or sprayed on the leaves $(50 \mathrm{ml} / \mathrm{pot})$. The experiment was terminated eight weeks after planting. At the end of experiment, the response of genotypes to nematode infection was rating based on number of gall scale (Table 1), according to Taylor and Sasser (1978).

\section{Statistical analysis:}

Data were statistically analyzed using the standard method of a Randomized Complete Blocks Design (R.C.B.D), illustrated by AlRawi and Khalf-Allah (1980). The least significant difference (L.S.D) was used to test the significance of differences among the various means (Snedecor and Cochran, 1973).

Table (1). Modified rating scale for the assessment of level of resistance or susceptibility based on number of galls.

\begin{tabular}{|c|c|l||}
\hline Number of galls & Galling index & \multicolumn{1}{|c|}{ Resistance rating } \\
\hline 0 & 0 & Immune (I) \\
$1-2$ & 1 & Highly resistant (HR) \\
$3-10$ & 2 & Resistant (R) \\
$11-30$ & 3 & Moderately resistant (MR) \\
$31-70$ & 4 & Moderately susceptible (MS) \\
$71-100$ & 5 & Susceptible (S) \\
$>100$ & 6 & Highly susceptible (HS) \\
\hline
\end{tabular}


Heterosis percentages: Heterosis relative to mid- parents (MPH\%) and better parent (BPH\%) were estimated, according to Mather and Jinks (1971)

Potence ratio $(\mathbf{P})$ : This parameter which determine the nature of dominance and its direction was estimated according to Smith (1952).

The genetic parameters, coefficient of variance (C.V. \%), Additive variance $(1 / 2 D)$, dominance variance $(1 / 4 \mathrm{H})$, broad and narrow sense heritability ( $\mathrm{BSH}$ and $\mathrm{NSH}$ ), predicted gain under selection $(\Delta \mathrm{G})$ and genetic advance under selection ( $\Delta \mathrm{G} \%$ ) were calculated according to Singh and Chaudhary (1995).

\section{RESULTS AND DISCUSSION}

The obtained results showed significant differences between the two parental genotypes in all studied characters. The analysis of variance of population means showed no significant differences at $5 \%$ level of significance among the replications for the studied traits. Therefore, data of the three replications of each population were pooled and handled for the genetic analysis. The estimated coefficient of variance (C.V.\%) of the studied populations for all studied characters showed that the non- segregating populations, i.e., $P_{1}, P_{2}$ and $F_{1}$ were the least variable comparing with the segregating ones, i.e., $F_{2}, B c p_{1}$ and $B c p_{2}$. This could be explained by the high homogeneity of the parents and $F_{1}$ plants, meanwhile, the segregating populations consist of homozygous and heterozygous plants.

\section{Number of days to fruit ripening:}

Data of this trait are illustrated in Table (2) and Figure (1). The means of the two parents were 80.3 and 61.1 days for $P_{1}$ (Super beef Steak) and $\mathrm{P}_{2}$ (Bl-15), respectively. This significant difference between the two parents is dependent on genotype as reported by Nassar (1988). The resulted cross $\left(P_{1} \times P_{2}\right)$ showed mean value of 57.8 days, indicating dominance towards the short period to maturity. The estimated negative mid-parent heterosis $(\mathrm{MPH})$ and better parent heterosis $(\mathrm{BPH})(-18.2 \%$ and $5.4 \%$, respectively) suggest over dominance for the short period to maturity which confirmed by potence ratio value (1.3). The dominance of the short period to maturity was also found in tomato by Midan et al. (2009).

Table (2). Means and coefficient of variance for number of days to fruit ripening and average fruit weight in the six tomato populations.

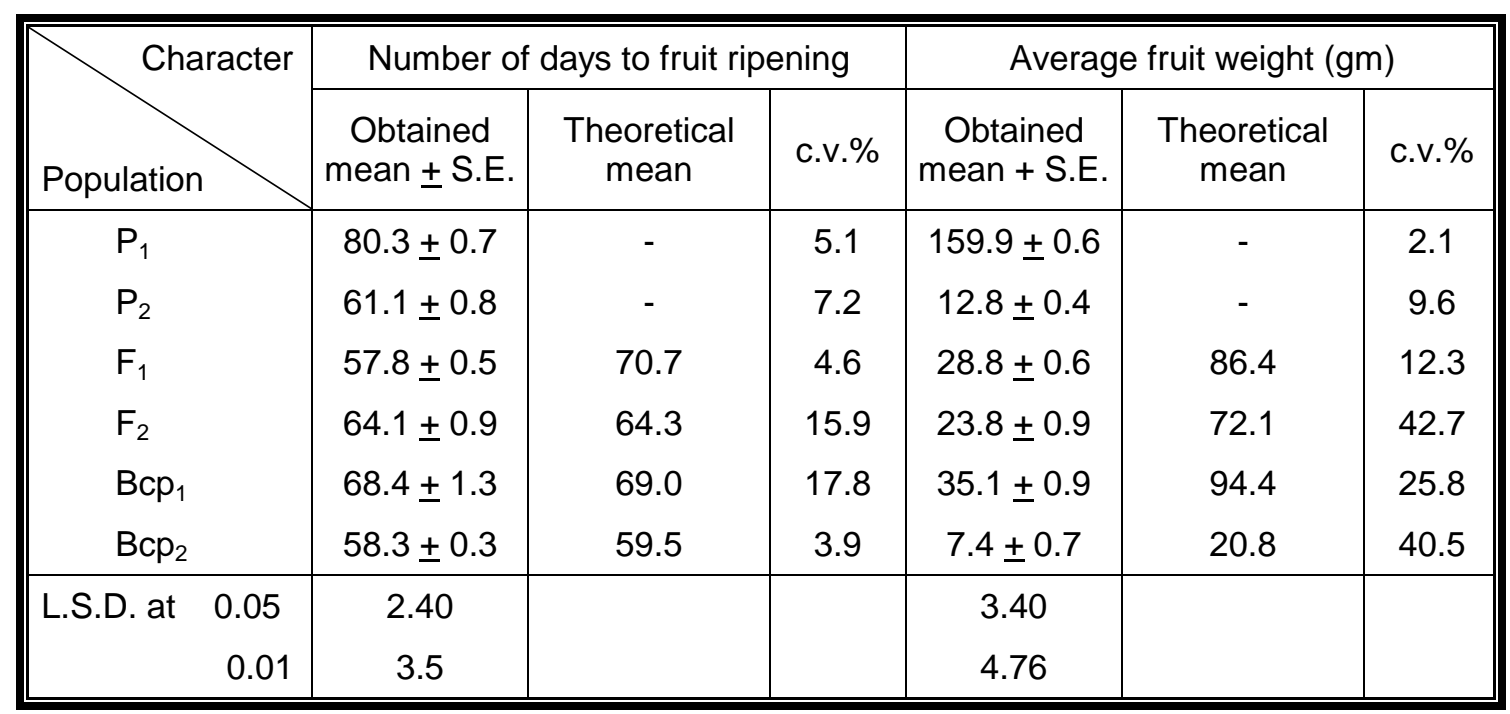



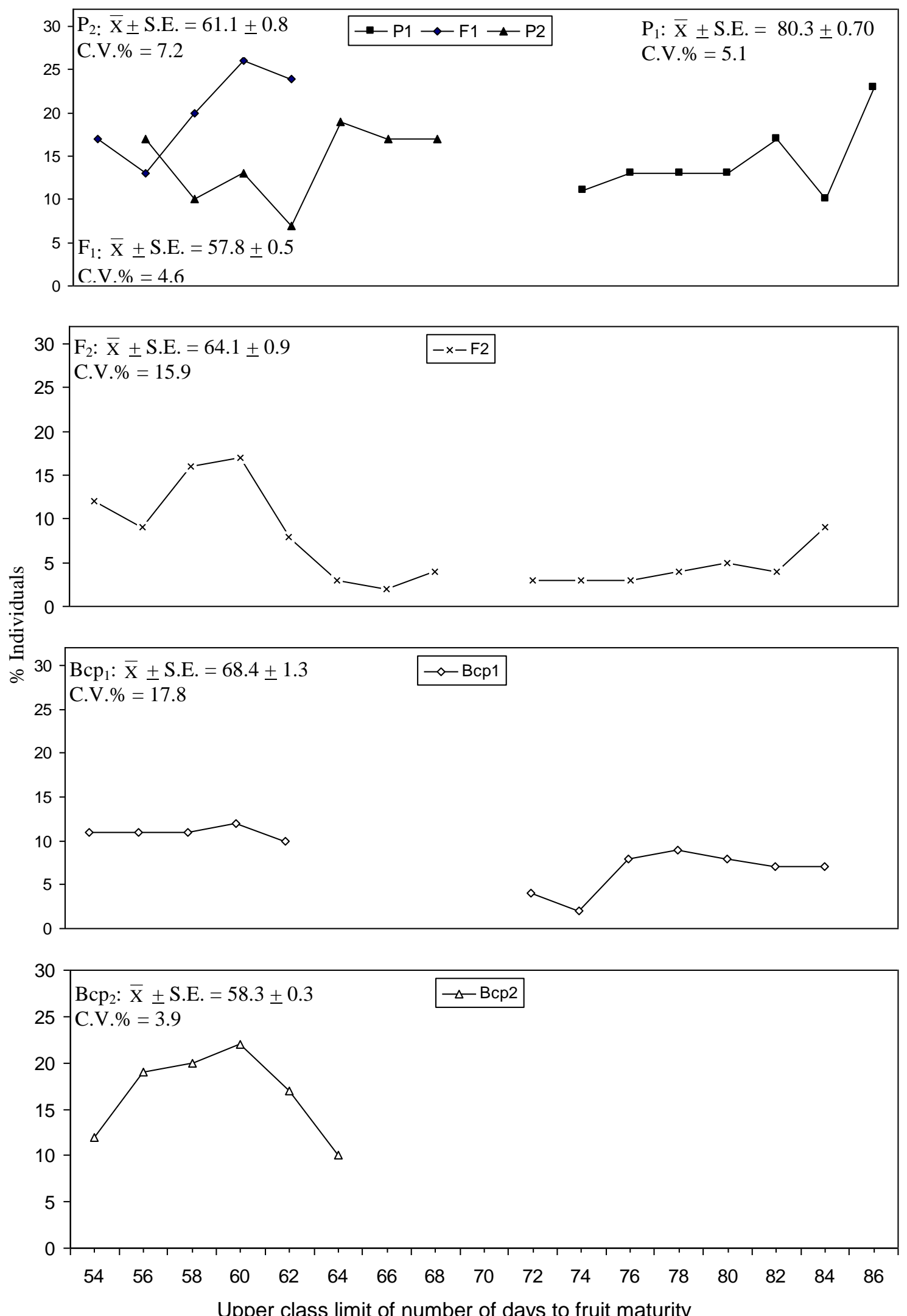

Figure (1). Distributions of number of days to fruit maturity in the six tomato populations. 
The average number of days (64.1) of $F_{2}$ exceed that of $F_{1}$ population with an inbreeding depression (I.D) values $-10.9 \%$, this may be due to the over dominance of the short period to maturity which was observed in $F_{1}$.

The means of $\mathrm{Bcp}_{1}$ and $\mathrm{Bcp}_{2}$ were significantly differed, this could be also explained by the over-dominance of the short period to maturity. It is noticed that the obtained means of $F_{2}, B_{c p}$ and $\mathrm{Bcp}_{2}$ were very close to the theoretical means, suggesting that this character might be simply inherited.

As shown in Figure (1), $F_{2}$ plants segregated into two classes with about 70 : $30 \%$ ratio. The first class was similar to $P_{2}$ and $F_{1}$ populations and the second class was similar to the latter (recessive) parent in ripening. The ratio is fit a $3: 1$ using $X^{2}$ test with probability of $0.20-0.50$ and support the mono-genic inheritance.

The $\mathrm{Bcp}_{1}$ plants segregated into two classes with a ratio of 55: $45 \%$. The first class was distributed within the range of $F_{1}$ and $P_{2}$, while the second class distributed within the range of $\mathrm{P}_{1}$ populations. This ratio was fit a $1: 1$ using
$\mathrm{X}^{2}$ test with a probability of $0.20-0.50$. On the other hand, the plants of $\mathrm{Bcp}_{2}$ were distributed within the range of $F_{1}$ and $P_{2}$ without any segregation, as expected when the character is controlled by single pair of genes with dominance for the short period to maturity. This conclusion is in agreement with that of Midan et al. (2009).

Data of Table (3) show that the estimated significant negative $\mathrm{MPH} \%, \mathrm{BPH} \%$ and potence ratio values were in accordance with the over-dominance hypothesis. The calculated $\mathrm{BSH}, \mathrm{NSH}, 1 / 2 \mathrm{D}$ and $1 / 4 \mathrm{H}$, indicated that both additive and dominance gene effects are involved in the inheritance of this trait. Furthermore, the estimated $\Delta G \%$, genetic advance under selection, showed that considerable progress for early fruit maturity could be achieved by heterosis breeding and selection. It could be concluded that the number of days from transplanting to fruit ripening, in this study, is controlled by single pair of genes with overdominance of the short period and presence of some additive gene effects and heterosis breeding could be used. This conclusion was also reported by Ahmed et al. (2006).

Table (3). Genetic parameters estimated for the studied traits.

\begin{tabular}{|c|c|c|c|c|c|c|}
\hline Character & $\begin{array}{l}\text { Number of } \\
\text { days to fruit } \\
\text { maturity }\end{array}$ & $\begin{array}{c}\text { Average } \\
\text { fruit weight }\end{array}$ & TSS & $\begin{array}{l}\text { Vitamin } \\
\text { C }\end{array}$ & $\begin{array}{l}\text { Number of } \\
\text { gall }\end{array}$ & $\begin{array}{c}\text { Number of } \\
\text { egg } \\
\text { masses }\end{array}$ \\
\hline 1. MP Heterosis & $-18.2^{* *}$ & $-66.65^{\star *}$ & $-11.0^{* *}$ & -0.17 & $-73.04^{\star *}$ & $-69.2^{\star \star}$ \\
\hline 2. BP Heterosis & $-5.4^{* *}$ & $-81.99^{* *}$ & $-27.7^{* *}$ & -29.48 & -8.33 & -8.0 \\
\hline 3. Potence ratio & 1.3 & -0.78 & -0.47 & -0.01 & 1.03 & 1.04 \\
\hline 4. $\mathrm{BSH}$ & 86.2 & 82.7 & 89.8 & 92.2 & 96.7 & 93.14 \\
\hline 5. $\mathrm{NSH}$ & 49.6 & 32.0 & 17.8 & 79.9 & 61.9 & 46.49 \\
\hline 6. $1 / 2 \mathrm{D}$ & 51.8 & 17.0 & 0.26 & 47.58 & 90.21 & 29.8 \\
\hline 7. $1 / 4 \mathrm{H}$ & 38.2 & 26.9 & 1.06 & 7.28 & 50.76 & 30.1 \\
\hline 8. $\Delta \mathrm{G}$ & 10.44 & 4.8 & 0.55 & 12.7 & 15.42 & 7.59 \\
\hline 9. $\Delta \mathrm{G} \%$ & 16.29 & 13.5 & 8.32 & 44.6 & 129.9 & 75.9 \\
\hline
\end{tabular}

${ }^{*},{ }^{* *}$ significant at 0.05 and 0.01 levels of probability, respectively. 


\section{Average fruit weight:}

The two parents significantly differed in average fruit weight (159.9 and $12.8 \mathrm{gm}$ ) for the cultivar Super Beef Steak $\left(P_{1}\right)$ and the line $\mathrm{Bl}-15\left(\mathrm{P}_{2}\right)$, respectively. The $\mathrm{F}_{1}$ mean $(28.8 \mathrm{gm})$ was very close to that of the small fruited parent with significant Mp-heterosis of $-66.7 \%$, indicating dominance towards the small fruited parent (Table 2). The estimated potence ratio $(-0.78)$ indicated partial dominance. The $F_{2}$ mean was slightly lower than the $F_{1}$ mean, this may be due to the partial dominance of the small fruit. Regarding the two backcrosses, the fruit of $\mathrm{Bcp}_{1}$ plants slightly exceeded that of $\mathrm{F}_{1}$ by about $22 \%$, while the average fruit weight of $\mathrm{Bcp}_{2}$ was significantly lower than that of $\mathrm{F}_{1}$ as shown in Table (2).

The $\mathrm{Bcp}_{1}$ and $\mathrm{Bcp}_{2}$ means (35.1 and 7.4) are different, supporting the dominance of small fruit weight. The obtained and theoretical means of all studied populations showed significant differences. This could be lead to suggest that the character is controlled by several genes. It is noticed that the actual means were always lesser than the expected means, supporting the dominance gene effects of the light fruit weight.

As shown in Figure (2) the plants of $F_{2}$ distributed over a wide range of fruit weight scale. All plants were similar to those of $P_{2}$ (small fruited parent) and $F_{1}$. None of plants were similar to $P_{1}$ (large fruited parent), due to the partial dominance of the light fruit. Also none of $\mathrm{Bcp}_{1}$ plants had average fruit weight similar to $P_{1}$, all plants lied in the distance of $F_{1}$ with slight skewness towards $P_{2}$, supporting the dominance toward the small fruit. With regard to $\mathrm{Bcp}_{2}\left(\mathrm{~F}_{1} \times \mathrm{Bl}-15\right)$, the plants were similar to $F_{1}$ and $P_{2}$ with about $50 \%$ for each of them as expected when the small fruit is dominant.

The obtained BSH (82.7\%), NSH (32.0\%), additive (17.0) and dominance (26.9) variance suggest that both additive and dominance gene effects are involved in the inheritance of average fruit weight in this cross. These findings are agreement with those of Ghosh et al. (2010) and Rajasekhar et al. (2013). All these findings lead to suggest that this character is controlled by several genes with partial dominance of the small fruit and presence of some additive gene effects.

\section{Total soluble solids (TSS\% content):}

Data of TSS\% are presented in Table (4) and illustrated in Figure (3). The means of the two parents showed significant difference in fruit TSS\% content (5.59 and $8.95 \%)$. The obtained mean of $F_{1}$ population $(6.47 \%)$ was between the mid-parents and the low parent $\left(P_{1}\right)$, indicating partial dominance for the low TSS\% content. The partial dominance was revealed by the estimated significant negative mid-parent heterosis (MPH), significant positive lowparent heterosis and potence ratio, values which were $-11.0,15.7 \%$ and 0.47 , respectively.

The means of $F_{1}$ and $F_{2}$ were approximately similar, indicating the presence of additive gene effects. The means of the two backcrosses differed, indicating also the presence of additive gene effects. However, the additive gene effects were verified by the approximation of theoretical and actual means of $\mathrm{Bcp}_{1}$ and $\mathrm{Bcp}_{2}$. Hence, it could be concluded that both additive and dominance gene effects are involved in the inheritance of this trait. This results were also found by Shirin and Hazra (2013).

Plants of the parents distributed without over lapping, the range was $4.8-6.1$ and $8.5-9.7 \%$ for $P_{1}$ and $P_{2}$, respectively. None of the $F_{1}$ plants were similar to the high parent $\left(P_{2}\right)$ in TSS\% content. While only five plants were similar to the low parent $\left(P_{1}\right)$ and the remaining plants ranged between the parent, indicating the importance of additive effects. 

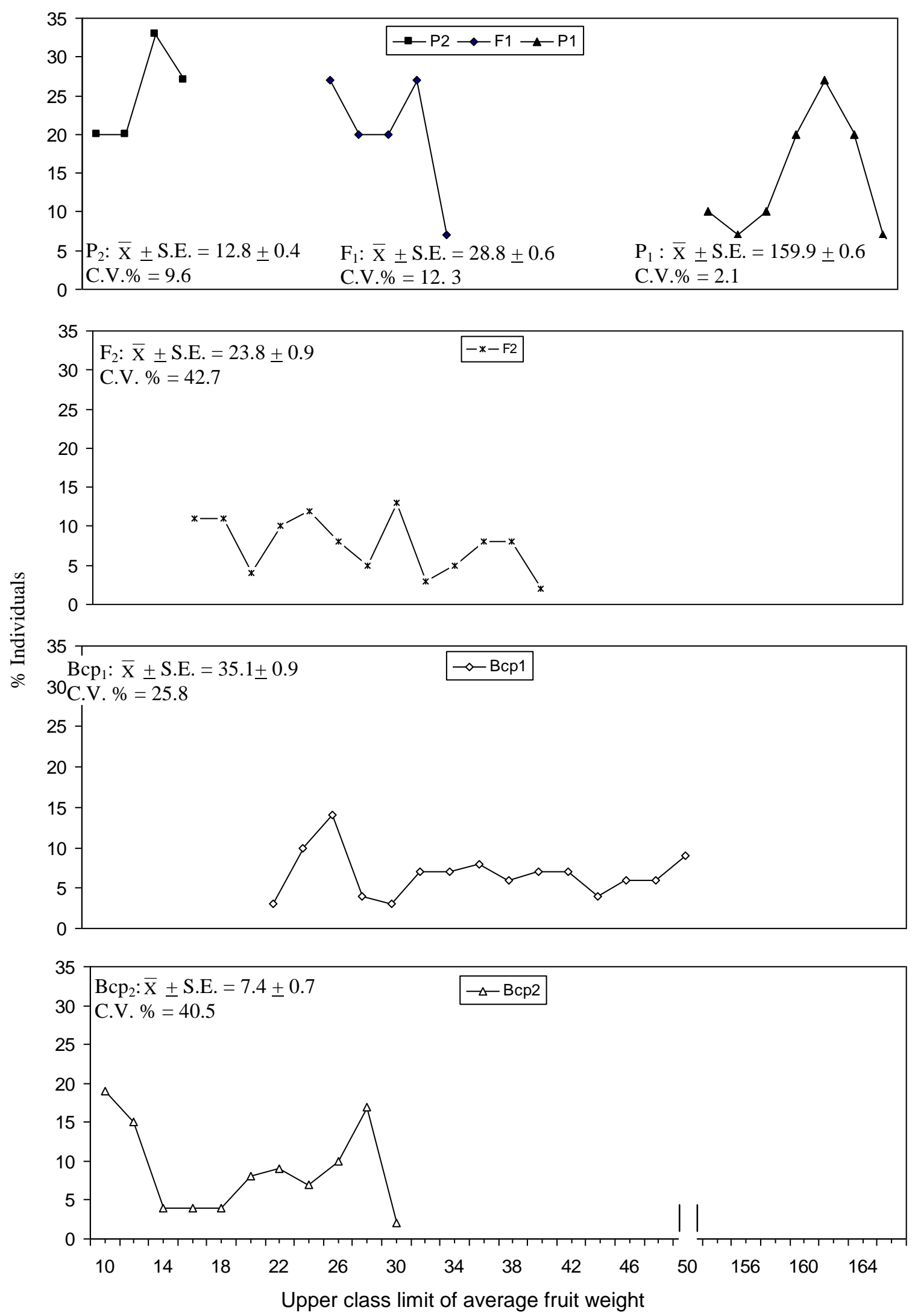

Figure (2). Distributions of average fruit weight in the six tomato populations. 

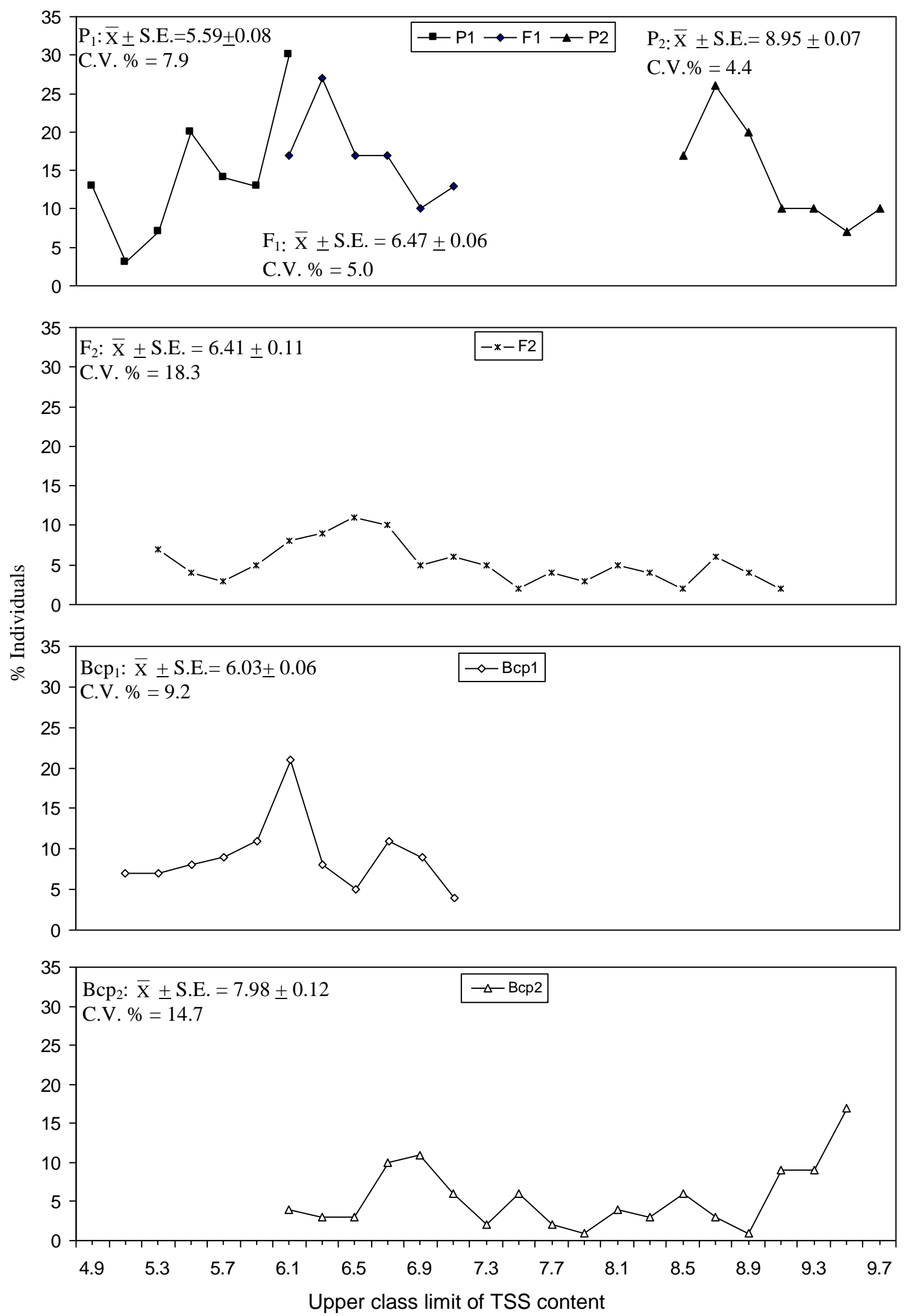

Figure (3). Distributions of TSS\% in the six tomato populations. 
Table (4). Means and coefficient of variance for total soluble solids (TSS \%) and ascorbic acid (vitamin C) contents in the six tomato populations.

\begin{tabular}{||c|c|c|c|c|c|c||}
\hline \multirow{2}{*}{ Character } & \multicolumn{2}{|c|}{ Total soluble solids (TSS) } & \multicolumn{3}{c|}{ Vitamin C } \\
\cline { 2 - 7 } & $\begin{array}{c}\text { Obtained } \\
\text { mean } \pm \text { S.E. }\end{array}$ & $\begin{array}{c}\text { Theoretical } \\
\text { mean }\end{array}$ & c.v.\% & $\begin{array}{c}\text { Obtained } \\
\text { mean + S.E. }\end{array}$ & $\begin{array}{c}\text { Theoretical } \\
\text { mean }\end{array}$ & c.v.\% \\
\hline $\mathrm{P}_{1}$ & $5.59 \pm 0.08$ & - & 7.9 & $16.8 \pm 0.33$ & - & 10.90 \\
$\mathrm{P}_{2}$ & $8.95 \pm 0.07$ & - & 4.4 & $40.7 \pm 0.45$ & - & 6.00 \\
$\mathrm{~F}_{1}$ & $6.47 \pm 0.06$ & 7.27 & 5.0 & $28.7 \pm 0.39$ & 28.75 & 7.70 \\
$\mathrm{~F}_{2}$ & $6.41 \pm 0.11$ & 6.87 & 18.3 & $28.5 \pm 0.70$ & 26.20 & 29.10 \\
$\mathrm{Bcp}_{1}$ & $6.03 \pm 0.06$ & 6.03 & 9.2 & $24.2 \pm 0.69$ & 22.75 & 27.11 \\
$\mathrm{Bcp}_{2}$ & $7.98 \pm 0.12$ & 7.50 & 14.7 & $34.2 \pm 0.56$ & 34.70 & 15.60 \\
\hline L.S.D. at 0.05 & 0.14 & & & 2.1 & & \\
0.01 & 0.19 & & & 2.9 & & \\
\hline
\end{tabular}

Regarding the $F_{2}$ plants, they distributed on a wide range $(5.3-9.1 \%)$. They covered the ranges of $P_{1}, F_{1}$ and $P_{2}$ populations suggest that the character is may be quantitatively inherited. The minimum number of gene pairs was estimated as three ones. The plants of $\mathrm{Bcp}_{1}$ occupied the range of both $\mathrm{P}_{1}$ and $\mathrm{F}_{1}$ plants $(4.9-7.3 \%)$ as expected due to the partial dominance genes of the low content. On the other hand, plants of $\mathrm{Bcp}_{2}$ (the recessive parent) stretched on a wide range $(6.1-9.5 \%)$. About 31 and $43 \%$ were similar to $F_{1}$ and $P_{2}$ populations, respectively. The remaining plants were between the two populations (Figure 3).

The estimated additive ( $(1 / 2$ D) and dominance $\left(\begin{array}{ll}1 / 4 & H\end{array}\right)$ effects support the importance of both additive and dominance gene effects in the inheritance of TSS\% content in this study. The additive gene effect was also clear from the estimated broad sense (BSH) and narrow sense (NSH) heritabilities which were 89.8 and $17.8 \%$, respectively. The presence of additive effect is useful and could be help in improvement TSS\% content by selection. Also, the calculated $\Delta G \%$ supported this suggestion.

All these findings lead to suggest that the total soluble solids content in tomato is controlled by several genes with additive gene effects and partial dominance of the low content. Accordingly, producing tomato lines or cultivars have high TSS\% content could be able by breeding and selection. The partial dominance for low TSS\% content, which reflected by the negative MPheterosis, was also found by Yashavantakumar (2008).

\section{Vitamin C:}

The means of both parents (16.8 and $40.7 \mathrm{mg} / 100 \mathrm{gm}$ ( $P_{1}$ and $P_{2}$, respectively) significantly differed in vitamin $C$ content. The $F_{1}$ mean $(28.7 \mathrm{mg} / 100 \mathrm{gm})$ is very close to the mid-parent value $(28.8 \mathrm{mg} / 100 \mathrm{gm})$. The low insignificant estimated MPH $-0.17 \%$ and potence $(0.01)$ values indicate nodominance for the character. The mean of $F_{2}$ (28.5), as expected, was approximately similar to that of $F_{1}(28.7)$, since the character is controlled by additive genes. On the other hand, the obtained $F_{2}$ mean was slightly higher than the theoretical mean as shown in Table (4). The two means of $\mathrm{Bcp}_{1}$ and $\mathrm{Bcp}_{2}$ populations (24.2 and 34.2, respectively) showed significant difference due to the high difference between the two parents in vitamin $\mathrm{C}$ content. The theoretical and obtained means of the two Backcrosses 
were close, suggesting that ascorbic acid content may be controlled by one pair of genes.

The distribution of $F_{1}$ plants clearly reveals the no-dominance gene action. None of the $F_{1}$ plants had vitamin $\mathrm{C}$ content similar to either parent, all plants were in between the two parents with a range of $26-32 \mathrm{mg}$. The $F_{2}$ plants distributed in a wide range $(16.0-44.0)$. About 22,48 and $20 \%$ of the plants were similar to $P_{1}, F_{1}$ and $P_{2}$ populations, respectively, in vitamin $C$ content. This ratio $(1: 2: 1)$ is fit a $X^{2}$ test with a probability of $0.75-0.90$. This ratio suggest that the trait may be controlled by one pair of genes with mostly additive effects (Fig 4).

The monogenic inheritance was also revealed by the distribution of $\mathrm{Bcp}_{1}$ and $\mathrm{Bcp}_{2}$ plants. About 56 and $47 \%$ of their plants were similar to the $F_{1}$ population in two backcross, respectively. Meanwhile, 44 and $43 \%$ were similar to $P_{1}$ and $P_{2}$ in $B_{c p}$ and $B \mathrm{Bp}_{2}$, respectively. The ratios $1: 1$ are fit a $\mathrm{X}^{2}$ test with a probability of $0.75-0.90$ for $\mathrm{Bcp}_{1}$ and $0.25-0.50$ for $\mathrm{Bcp}_{2}$ according to monogenic hypothesis. The additive gene effects were more importance in the inheritance of this trait as reported by Megahed (2002) and Mostafa (2015).

The calculated insignificant mid-parents heterosis $(-0.17 \%)$, potence ratio $(-0.01), 1 / 2$ $\mathrm{D}(47.58)$ and $1 / 4 \mathrm{H}(7.28)$ values support the postulated monogenic inheritance of vitamin $C$ content with mostly additive gene effects and slight dominance of the low content. The high obtained $\mathrm{BSH}$ (92.2\%) and $\mathrm{NSH}$ $(79.9 \%)$ are in accordance with the qualitative character. Therefore, the vitamin C content could be improved by selection. Genetic advance under selection ( $\Delta G \%$ ) was found as $44.6 \%$. The high genetic advance under selection with high BSH were also reported by Rajasekhar (2013) and Mostafa (2015).

\section{Resistance to root knot nematode disease:}

The cross "Super Beef Steak $\times$ BI-15" was used in studying the inheritance of tomato resistance to root-knot disease caused by Meloidogene incognita. The super Beef Steak (SBS) which is considered as moderately susceptible cv., as reported by El-Shennawy and Khalil (2014), was used as female parent, while the resistant line $\mathrm{Bl}-15$ was used as male parent. Number of galls per root and egg masses were considered as indicator to degree of resistance for the studied populations $\left(P_{1}, P_{2}, F_{1}, F_{2}, B_{c p}\right.$ and $\left.B \mathrm{Bp}_{2}\right)$. Data obtained are illustrated in Tables (3 \&5) and Figures (5 \& 6).

Table (5). Means and coefficient of variance for root-knot nematode resistance as number of galls and egg masses in the six tomato populations.

\begin{tabular}{||c|c|c|c|c|c|c||}
\hline \multirow{2}{*}{ Character } & \multicolumn{3}{|c|}{ Gall number } & \multicolumn{3}{c||}{ Egg masses } \\
\cline { 2 - 7 } & $\begin{array}{c}\text { Obtained } \\
\text { mean } \pm \text { S.E. }\end{array}$ & $\begin{array}{c}\text { Theoretical } \\
\text { mean }\end{array}$ & c.v.\% & $\begin{array}{c}\text { Obtained } \\
\text { mean + S.E. }\end{array}$ & $\begin{array}{c}\text { Theoretical } \\
\text { mean }\end{array}$ & c.v.\% \\
\hline $\mathrm{P}_{1}$ & $34.8 \pm 0.5$ & - & 7.9 & $23.7 \pm 0.55$ & - & 12.9 \\
$\mathrm{P}_{2}$ & $6.0 \pm 0.4$ & - & 35.2 & $4.7 \pm 0.25$ & - & 28.9 \\
$\mathrm{~F}_{1}$ & $5.5 \pm 0.3$ & 20.4 & 28.5 & $4.8 \pm 0.27$ & 14.2 & 27.5 \\
$\mathrm{~F}_{2}$ & $11.87 \pm 0.9$ & 13.1 & 101.7 & $10.1 \pm 0.77$ & 9.25 & 80.1 \\
$\mathrm{Bcp}_{1}$ & $18.1 \pm 1.5$ & 20.2 & 77.9 & $12.6 \pm 1.03$ & 14.0 & 77.6 \\
$\mathrm{Bcp}_{2}$ & $5.9 \pm 0.2$ & 5.7 & 26.6 & $5.7 \pm 0.18$ & 4.5 & 32.2 \\
\hline L.S.D. at 0.05 & 1.2 & & & 1.0 & & \\
0.01 & 1.7 & & & 1.4 & & \\
\hline
\end{tabular}



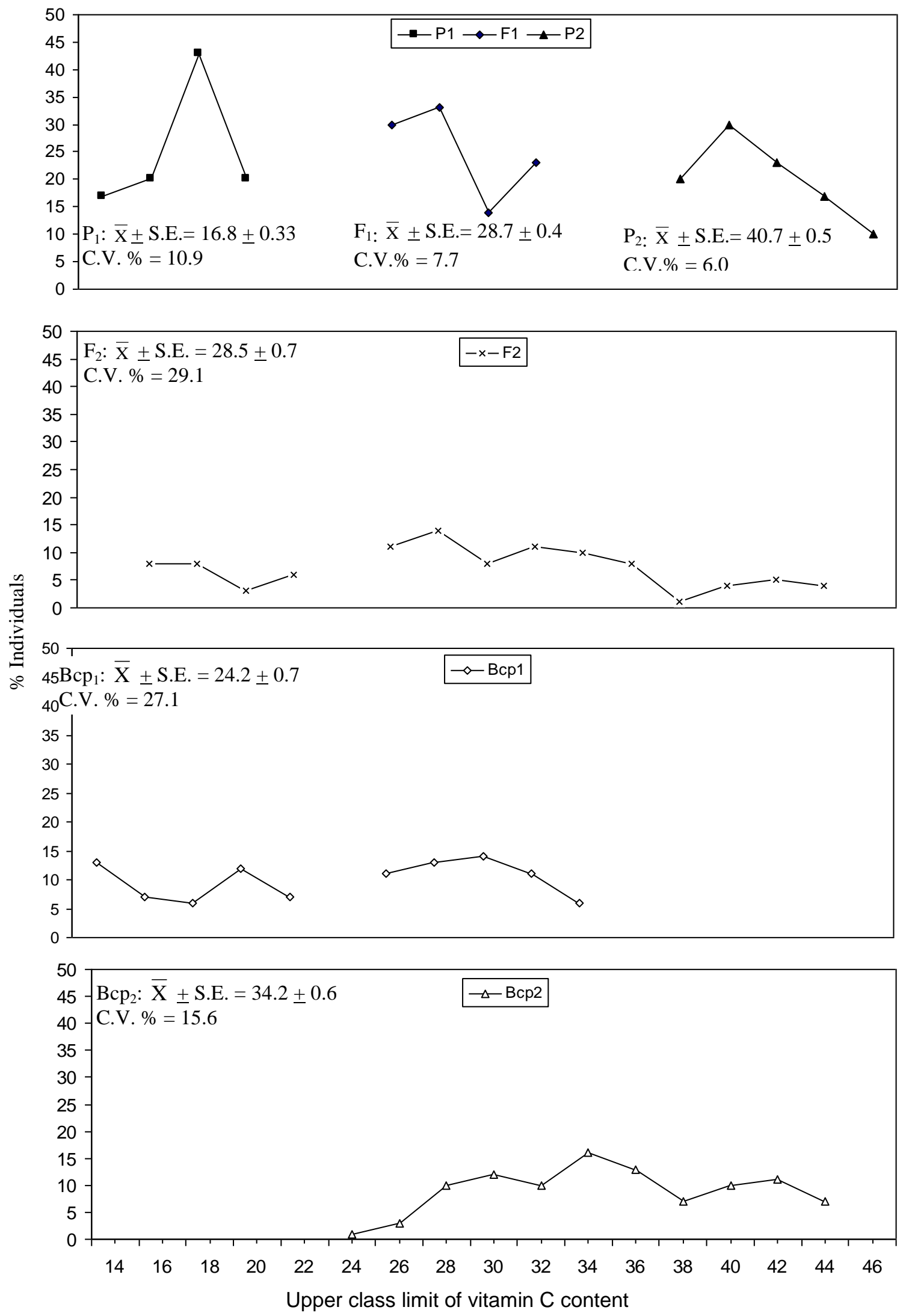

Figure (4). Distributions of vitamin C content in the six tomato populations. 

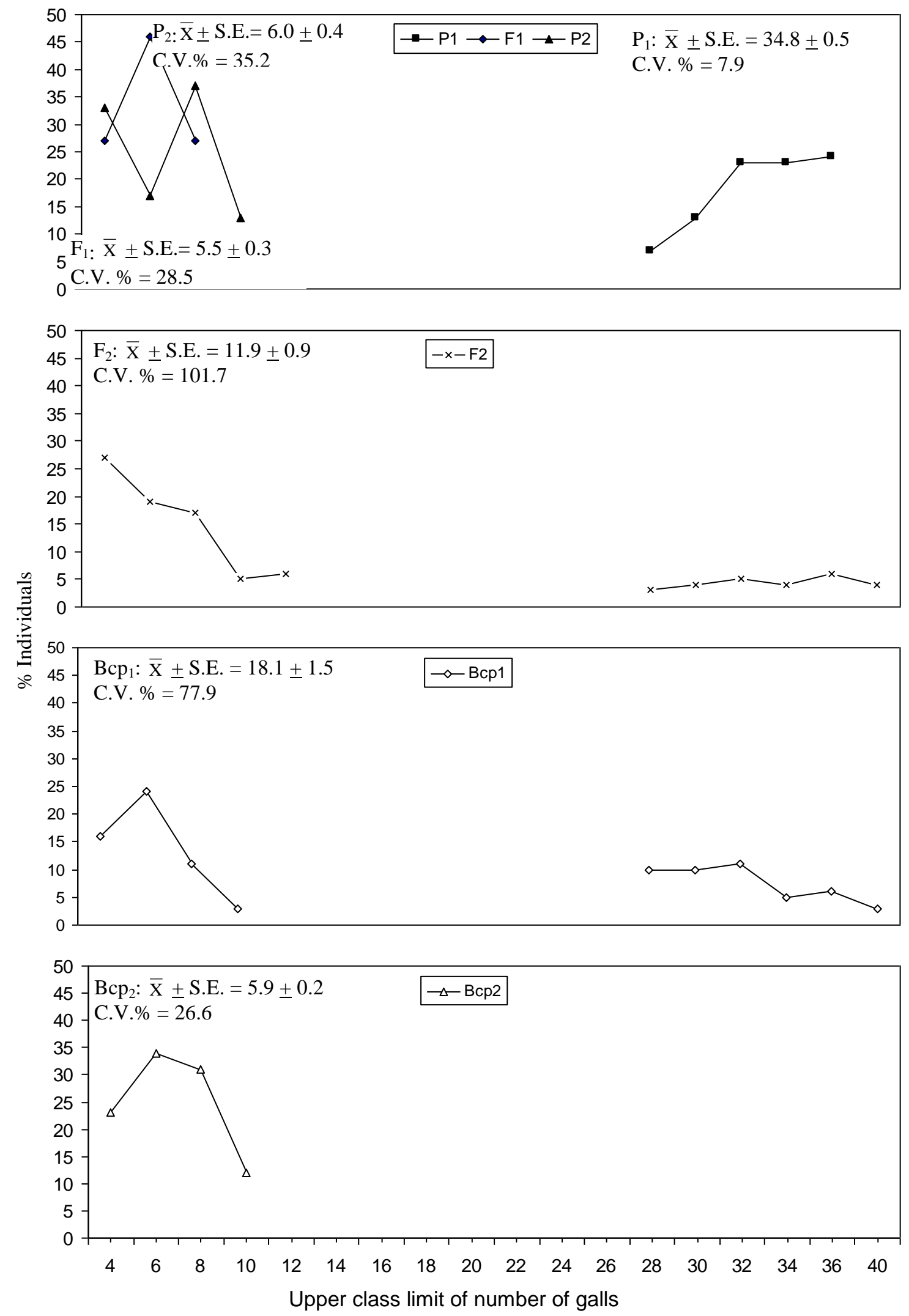

Figure (5). Distributions of number of galls / plant in the six tomato populations. 

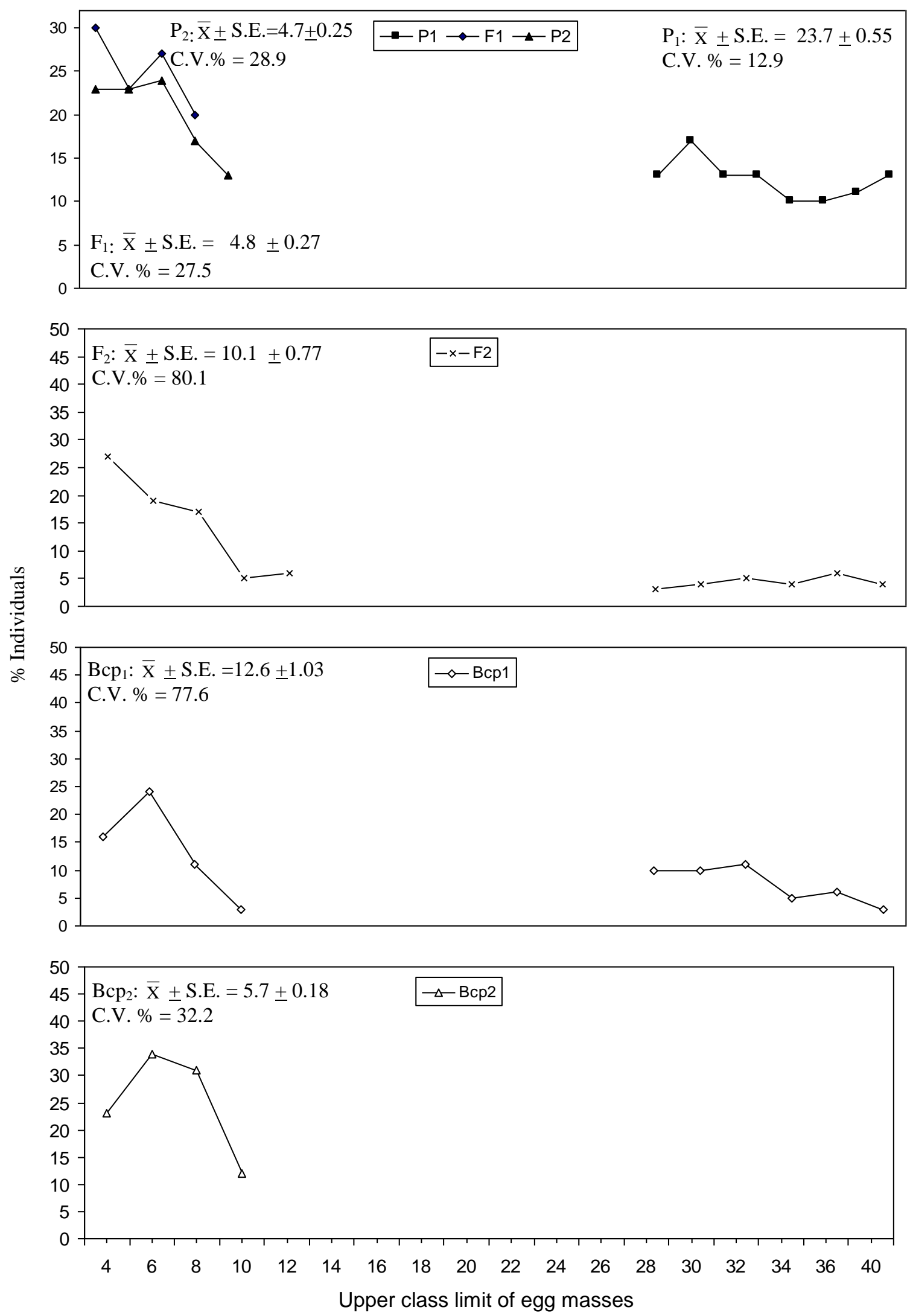

Figure (6). Distributions of egg masses in the six tomato populations. 


\subsection{Number of galls:}

The parents significantly differed in gall number / root. It ranged from $29-38$ with an average of 34.8 in $\mathrm{P}_{1}$ [Moderately susceptible cv. (MS)], and from $3-9$ with an average of 6.0 galls in $P_{2}$ [the resistant parent $(R)]$. The mean of $F_{1}$ population (5.5) was very close to that of $P_{2}$ (R.P.), indicating dominance for the resistant genes over the susceptible ones. The estimated significant negative $\mathrm{MPH}$, insignificant negative $\mathrm{BPH}$ (-73.04 and $-8.33 \%$, respectively) and positive potence ratio (1.03) together support the dominance of the resistance genes. Similar results was also reported by Khalil and Salem (1983) and Mark (1986).

$F_{2}$ mean (11.87) was higher than $F_{1}$ and $\mathrm{P}_{2}$ means as expected when the character is controlled by dominant genes. The obtained $\mathrm{Bcp}_{1}$ and $\mathrm{Bcp}_{2}$ means (18.1 and 5.9, respectively) were differed, due to the dominance gene effects. The actual means of $F_{2}, B c p_{1}$ and $\mathrm{Bcp}_{2}$ suggesting that resistance may be controlled by one pair of genes. According to rating scale (Table 1), the $\mathrm{P}_{2}, \quad \mathrm{~F}_{1}$ and $\mathrm{Bcp}_{2}$ populations are resistant, meanwhile, $F_{2}$ and $B_{c p_{1}}$ populations are moderate resistant (MR). The monogenic inheritance was previously suggested by Khalil and Salem (1983) and Mark (1986) in tomato.

Distribution of the segregating populations support the postulated dominance hypothesis. Figure (5) show that $F_{2}$ plants distributed in two groups with a ratio of $3: 1$ with a probability of $0.05-0.10$, the first is similar to both $F_{1}$ and $P_{2}$ (R.P), and the second group is similar to $P_{1}$ (S.P). The plants of $\mathrm{Bcp}_{1}\left(\mathrm{~F}_{1} \times \mathrm{S} . \mathrm{P}\right)$ also distributed is two similar classes (1: 1) with a probability of $0.25-0.50$. On the other hand, all plants of $\mathrm{Bcp}_{2}\left(\mathrm{~F}_{1} \times\right.$ R.P $)$ were similar to $F_{1}$ and $\mathrm{P}_{2}$ without distinct classes. The distribution of $\mathrm{F}_{2}, \mathrm{Bcp}_{1}$ and $\mathrm{Bcp}_{2}$ is in accordance with the monogenic inheritance of this character.

The genetical parameters estimates (Table 3) are in agreement with the simply inherited characters. High BSH (96.7\%), $\mathrm{NSH}(61.9 \%), 1 / 2 \mathrm{D}(90.27), 1 / 4 \mathrm{H}(50.8)$ and $\Delta \mathrm{G} \%(129.9 \%)$ indicate that both additive and dominance effects are involved in the inheritance of resistance to root-knot nematode disease. Therefore, it could be concluded that this trait may be controlled by one pair of genes with dominance to high degree of resistance and presence of some additive effects. Heterosis breeding could be used to produce tomato $F_{1}$ hybrids resistant to this disease. Also selection programme could be applied to develop new resistant lines or cultivars for commercial production. The $F_{2}$ population have high degree of resistance, hence it might be used in tomato production in the infected soil.

\subsection{Egg masses:}

Data of egg masses are presented in Tables (3 and 5), and Figure (6). A comparison between data presented on the inheritance of both gall number and egg masses reveal a striking similarity between the two characters in their modes of inheritance. Much similarity were observed between the two characters in respect to relative values of c.v.\% (variances), distribution patterns of parents, $F_{1}, F_{2}, B_{c p}$ and $\mathrm{Bcp}_{2}$ populations. The estimated parameters such as MP and BP-heterosis, potence ratio, $\mathrm{BSH}$ and $\mathrm{NSH}$, additive and dominance gene effects and genetic advance under selection ( $\Delta \mathrm{G} \%)$ also followed the same trend with very close values (Table 5). Consequently, it is clearly apparent that the mode of inheritance of gall number and egg masses is identical. Accordingly, it is concluded that the two characters are controlled by one pair of genes with dominance of resistance over susceptible genes and follow the same mechanism of inheritance. The high association between the two traits lead to suggest that the determine of degree of resistance to root-knot nematode disease in tomato could be done by number of galls only. 
This was the first attempt to determine the relationship between the genetics resistance of tomato to root-knot nematode disease as gall number and egg masses. $\mathrm{A}$ critical review of the literature on the subject failed to reveal any report on this nature.

\section{REFERENCES}

Ahmed, N., M.I. Khan and A.J. Gupta (2006). Variability and heritability in tomato (Solanum lycopersicon, Mill.). Environment and Ecology, 245 (special 2): $386-388$.

Ahmed, S., A. K. M. Quamruzzaman and M.R. Islam (2011). Estimates of heterosis in tomato (Solanum lycopersicum, L.). Bangaldesh J. Agri.Res. 36(3): 521-527.

Al-Rawi, K. M. and A. M. Khalf-Allah (1980). Design and analysis of agriculture experiments. Text Book, El-Mousil Univ. Press. Ninwa, Iraq, p. 287.

El-Shennawy, M.Z. and Mona R. Khalil (2014). Evaluation of some tomato genotypes against the root-knot nematode, M. incognita. Zagazig J. Agric. Res. 41 (3): 479 - 489.

Foolad, M.R. (2007). Genome mapping and molecular breeding of tomato. Int. J. Plant Genome, 1: 1 - 52.

Ghosh, K.P., A.K.M.A. Islam and M.M. Hussain (2010). Variability and character association in $F_{2}$ segregating population of different commercial hybrids of tomato (Solanum lycopersicon L.). J. Appl. Sci., Environ. Manage, 14 (2): 91 - 95.

Hussey, R.S. and K.R. Barker (1973). A comparison of methods of collection inocula of Meloidogyne spp. including a new technique. Plant Disease Reporter, 57: 1025 - 1028.

Khalil, R.M. and F.M. Salem (1983). Inheritance of root-knot nematode in tomato interspecific cross. $1^{\text {st }}$ Hon. Con. Agric. Bot. Sci., 2 - 3 Feb. Mansoura Univ., pp. $1-9$.

Khalil, R.M.; A. A. Midan and N. M. Malash (1986). Genetical studies on vitamin C and total soluble solids in tomato fruits Lycopersicon esculentum Mill. Minufiya G.
Agric. Res., 11 (2): 917-932.

Knopp, S., L. Bush, M. Nee and D.M. Spooner (2004). Solanceae. A model linking genomics with biodiversity. Genome, 5: 285 - 291.

Kumar, S. and M.K. Sharma (2011). Exploitation of heterosis for yield and its contributing traits in tomato, (Solanum lycopersicon L.). Inet. J. Farm. Sci., 1: 45 $-55$.

Mahendrakar, P. (2004). Development of $F_{1}$ hybrids in tomato ( $L$. esculentum, Mill.). M.Sc. Thesis, Agric. Sci., Dharwad Univ.

Mark, J. Bassett (1986). Breeding vegetable crops, chapter 4. AVI Publishing company.IMC.

Masry, A.I. (2014). Heterosis and gene action in tomato crosses under tomato yellow leaf curd virus. Ph.D. Thesis Fac. Agric., Khafr El-Sheikh Univ., Egypt.

Mather, K. and J. L. Jinks (1971). Biometrical genetics. $2^{\text {nd }}$ Ed., Chapman and Hall, LTD. London. P. 382.

Megahed, E.M. (2002). Heterosis and gene action in varietal crosses of tomato Under North Sinai Conditions. M.Sc. Thesis, Fac. Environ., Agric. Sci. El-Arish, Suez Canal Univ., Egypt.

Midan, A.A., M.A. Fattahallah, A.A. Nawar and Mona R. Khalil (2009). Mode of inheritance of earliness in tomato. Menoufia J. Agric. Res., 34 (4): 1649 1664.

Mostafa, A.B.El. (2015). Genetical studies on tomato under North Sinai conditions. M.Sc. Fac. Environ. Agric. Sci., El-Arish, Suez Canal Univ., p. 218.

Nassar, H.H. (1988). evaluation of yield and fruit characterstics of some tomato $F_{1}$ hybrids grown in Fayoum. Egypt. Annals Agric. Sci., Fac. Agric., Ain Shams Univ., Cairo, Egypt, 33 (1): $399-410$.

Rajasekhar, R., D. Siddeswar, K. Reddaiah and N. Suntil (2013). Studies on genetic variability, heritability and genetic advance for yield and quality traits in tomato (Solanum Iycopersicon L.). Int. J. Curr. Microbiol. App. Sci., 2 (9): 238 - 244.

Rajesh, K., N.K. Mishra, J. Singh, G.K. Rai, 
A. Virma and M. Rai (2006). Studies on yield and quality traits in tomato (Solanum lycopersicum, Mill.). Veg. Sci., 33 (2): 126132.

Roberts, P.A. and D.M. May (1986). Meloidogyne incognita resistance characteristics in tomato genotypes developed for processing. J. Nematol., 18: $353-359$.

Rudi, H.M., M. Fardatun, R. Tafa and I. Siwi (2012). Early steps of tomato breeding resist to root-knot nematode. Agrivita, 34 (3): $267-274$.

Shirin, A. and P. Hazra (2013). Nature of gene action for fruit quality characters of tomato (Solanum lycopersicum). African J. Biotechnology, 12 (20): 2869 - 2875.

Singh, R.K. and B.D. Chaudhary (1995). Biometrical methods in quantitative genetic analysis. Kalyani Publisher, New Delhi 110002, India.

Singh, C.B., N. Rai, R.K. Singh, M.C. Singh, A.K. Singh and A.K. Chaturvedi (2008). Heterosis, Combining ability and gene action studies in tomato (Solanum lycopersicon L.). Veg. Sci., 35: $132-135$. Smith, H. H. (1952). Fixing transgressive vigour in nicotiana rustica. In heterosis lowa state College Press. Ames, lowa, USA.

Snedecor, G. W. and W. G. Cochran (1973). Statistical Methods. Iowa State Univ., Press, Ames. lowa. U.S.A.

Tendulkar, S.K. (1994). Studies on line $x$ tester analysis for development of $F_{1}$ hybrids in tomato (Solanum lycopersicon, Mill.). M.Sc. Thesis, Agric. Sci., Dharwad Univ.

Taylor, A.L. and J.N. Sasser (1978). Biology, identification and control of root-knot nematodes (Meloidogyne spp.). A cooperative publication of North Carolina State University, Department of Plant Pathology and USAID, Raleigh, NC. USA.

Yashavantakumar, K.H. (2008). Heterosis and combining ability for resistance against to spovirus in tomato (Solanum lycopersicon, Mill.). M.Sc. Thesis, Fac. Agric. Dharwad Univ. 
وراثة بعض الصفات الثمرية وصفة المُقاومة لمرض تعقُّ الجذور النيماتودي في الطماطم

منى رشدي خليل(1) ، محمد زكى الشناوي(2)

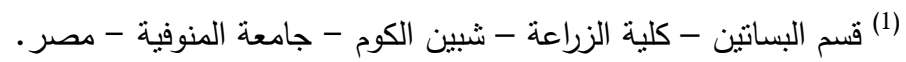

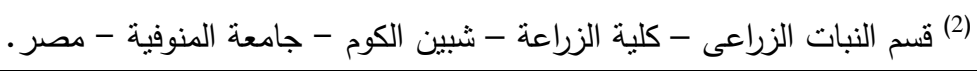

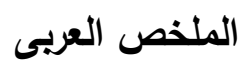

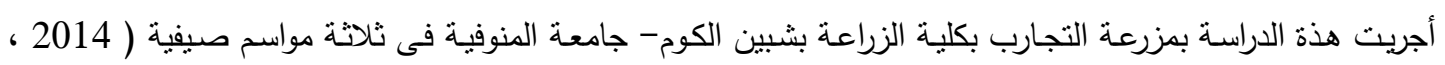

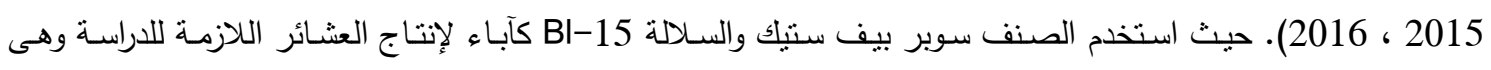

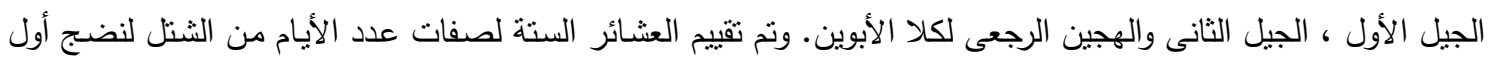

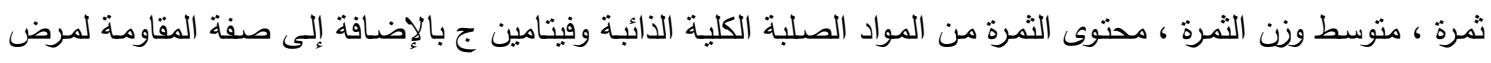

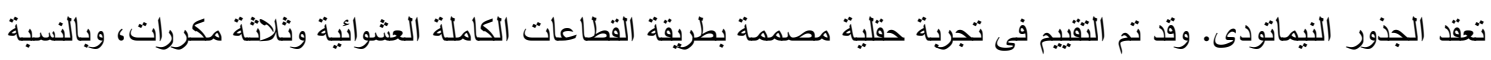
لتجربة النيماتودا فقد تم التقييم فى تجربة أصص بنفس التصميم وتم تسجيل البيانات لجميع الصفات على النباتات الفردية ثم

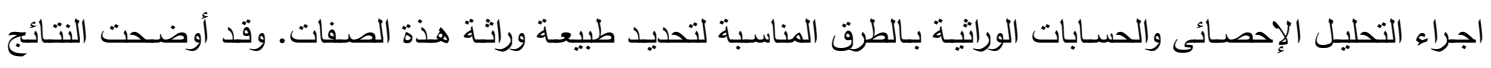

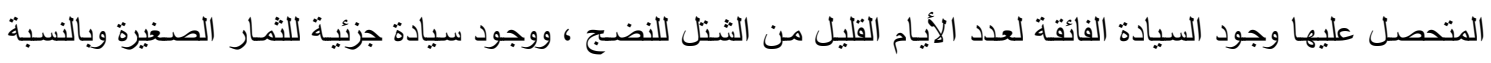

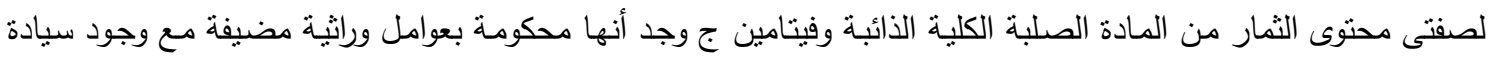

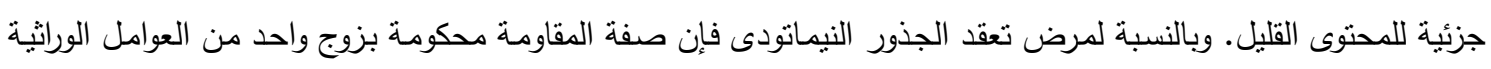

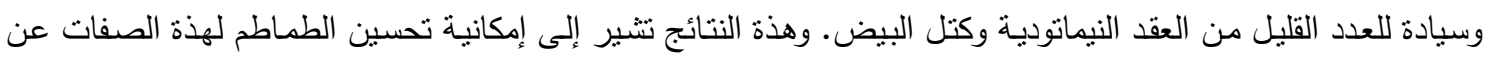

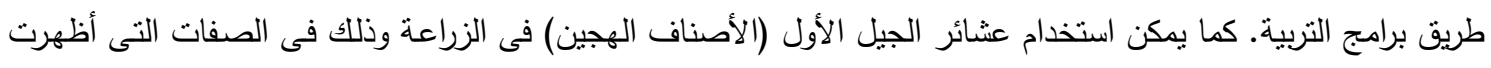

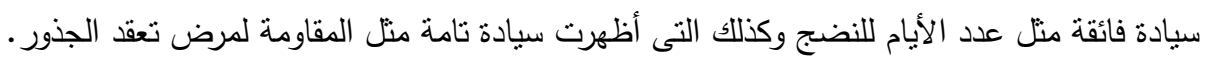


Inheritance of some fruit characters and resistance to root-knot .................. 